\title{
PENCAPAIAN KEMAMPUAN BERPIKIR GEOMETRI TINGKAT RENDAH SISWA: ANALISIS BERDASARKAN TIPE PEMBELAJARAN KOOPERATIF
}

\author{
Harun Al Afgoni ${ }^{1}$, Fiki Alghadari ${ }^{2 *}$, Niken Vioreza ${ }^{3}$ \\ ${ }^{1,2,3}$ STKIP Kusuma Negara Jakarta \\ *alghar6450@gmail.com
}

Diterima: 02 Juni 2020 Disetujui: 08 Juli 2020 Dipublikasikan: 31 Juli 2020

\begin{abstract}
ABSTRAK
Dua unsur penting dalam proses pembelajaran di sekolah adalah bagaimana pemahaman dan aktivitas belajar siswa. Di sisi lain, sebagian besar siswa hanya menghafal rumus algoritmik tanpa memahami konsepnya secara mendalam. Akibatnya, kemampuan berpikir siswa pada tingkat rendah menjadi dominan dalam operasional pembelajaran. Studi ini dilakukan dengan tujuan menganalisis pencapaian kemampuan berpikir geometri tingkat rendah siswa antara kelompok pembelajaran think pair share (TPS) dan two stay to stray (TSTS). Studi kuantitatif ini dilakukan pada siswa di salah satu sekolah menengah pertama (SMP) di daerah Jakarta Timur. Data diperoleh menggunakan instrumen yang dikembangkan berdasarkan tiga level awal berpikir geometri menurut teori van Hiele. Data dianalisis dengan statistik parametrik. Hasil analisis data menyimpulkan bahwa ada perbedaan pencapaian kemampuan berpikir geometri tingkat rendah siswa kelompok pembelajaran TPS dan TSTS. Berdasarkan statistik deskritif, rataan pencapaian siswa kelompok TPS lebih dari TSTS. Menurut hasil studi ini, belajar geometri pada konsep segitiga untuk siswa SMP disarankan dengan pembelajaran TPS. Ada indikasi berdasarkan sebaran data bahwa level berpikir geometri siswa sebagian besar berada pada level analisis.
\end{abstract}

Kata kunci: kemampuan berpikir geometri, low order thinking, pembelajaran kooperatif.

\begin{abstract}
Two important elements in learning process at school are how students' understanding and learning activities are. On the other hand, most students only memorize algorithmic formulas without understanding the concept in depth. As a result, students' thinking abilities at low levels in learning operations dominantly. This study aims is to analyze the achievement of students' low-level geometry thinking abilities between learning group of think pair share (TPS) and two stay to stray (TSTS). The sample of this quantitative study is students in junior high schools at East Jakarta. Data were obtained using instruments developed based on the first three geometrical thinking level according to van Hiele's theory. Data were analyzed by parametric statistics. The results of data analysis concluded that there are differences in achievement of students' low-level geometry thinking ability in TPS and TSTS learning groups. Based on descriptive statistics, the average achievement of TPS group is more than TSTS. According to the results of this study, learning geometry on triangle concept for junior high school students is suggested by learning TPS. There are indications based on the data distribution that the level of thinking of students in geometry is mostly at the analysis level.
\end{abstract}

Keywords: cooperative learning, geometry thinking ability, low order thinking.

\section{Pendahuluan}

Pendidikan merupakan proses pembelajaran yang dilakukan seseorang agar akal dan pikirannya selalu berkembang dan meningkat, sehingga mampu mengikuti perkembangan zaman yang semakin maju. Dengan pendidikan yang telah dijalaninya, maka diharapkan seseorang mampu menghadapi dan menyelesaikan setiap masalah yang ada, baik dalam kehidupan bermasyarakat, di sekolah, maupun di lingkungan pekerjaan. Pendidikan yang baik dan berkualitas sangat penting demi tercapainya tujuan pendidikan yang diharapkan. Namun, pendidikan geometri saat ini masih menjadi isu di dunia dan menjadi ilmu pengetahuan yang tidak mudah dipelajari siswa di sekolah.

Menurut beberapa hasil penilaian, ada masalah dengan pencapaian geometri siswa di Indonesia (Alghadari, Herman \& Prabawanto, 2020). Hasil observasi menurut studi Tarwana, Alghadari \& Marlina (2019) menemukan bahwa pemahaman konsep geometri rendah serta aktivitas belajar mereka yang masih 


\section{Range: Jurnal Pendidikan Matematika Vol. 2 No. 1 Tahun 2020 Harun Al Afgoni, dkk}

kurang berpartisipasi padahal keduanya merupakan unsur penting dalam proses pembelajaran di sekolah. Kemudian, dalam studi Alghadari \& Herman (2018) disebutkan bahwa ada ketidaksingkronan antara beberapa konsep yang digunakan sehingga tidak saling melengkapi satu dan yang lain untuk membuat penyelesaian yang benar. Menurut catatan studi tersebut, siswa yang tidak menyelesaikan masalah geometri dikarenakan mereka belum mampu mengkaitkan antara pengetahuan dan konsep yang telah dipelajari sebelumnya dengan masalah yang sedang dikerjakan. Selain itu, sebagian besar siswa hanya menghafal rumus algoritmik tanpa memahami konsepnya secara mendalam (Rahayu \& Alghadari, 2019). Padahal, pekerjaan siswa biasanya hanya menyelesaikan soal matematika sebatas mempresentasi atau mengaplikasi hal-hal rutin yang hanya melibatkan kemampuan berpikir tingkat rendah (Theresia, Syafi'i \& Vioreza, 2020).

Berdasarkan hasil studi Sudirman, Son, Rosyadi \& Fitriani (2020), secara umum bahwa siswa yang memahami konsep geometri adalah mereka yang mampu secara verbal menyatakan konsep materi, mengklasifikasikan konsep berdasarkan syarat tertentu, menerapkan konsep baik secara algoritmik maupun dalam berbagai bentuk representasi. Sementara syarat untuk mempelajari konsep lanjutan suatu materi adalah pemahaman pada konsep dasar dan keluasan jaringan informasi supaya pembelajaran mampu menghadirkan pengalaman kepada siswa (Rosilawati \& Alghadari, 2018; Minarti, Wahyudin \& Alghadari, 2018). Merujuk pada hasil studi tersebut dan menyejajarkannya dengan tingkatan kemampuan kognitif siswa dalam taksonomi, maka kemampuan-kemampuan tersebut merupakan kemampuan berpikir geometri tingkat rendah, atau dalam Theresia dkk. (2020) disebut dengan low order thinking. Oleh karena itu, tugas berat menanti seorang fasilitator di ruang kelas geometri untuk mampu mengkondisikan pengetahuan siswa yang terfragmentasi supaya mereka membangun jaringan antar konsep-konsep ke dalam skema kognitifnya sementara ada jarak waktu yang cukup panjang saat siswa mempelajari kembali chapter-chapter yang termasuk dalam ruang lingkup materi geometri (Alghadari dkk., 2020).

Belajar geometri tidak lepas dari peran bentuk visual sebagai suatu representasi konsep abstrak (Alghadari dkk., 2020). Oleh karen itu, lebih baik apabila menggunakan setting yang tepat dalam menyampaikan pembelajaran geometri, agar siswa dapat menyerap dan menangkap materi atau konsep (Rahmawati, Kusuma \& Suparman, 2020). Dalam kurikulum untuk sekolah tingkat menengah, geometri mempelajari tentang hubungan antara unsur-unsur geometri atau hubungan antar properti suatu bidang geometri (Minarti dkk., 2018). Selama ini, proses belajar-mengajar kadang masih menganut pada pembelajaran konvensional (Alghadari dkk., 2020; Rahmawati dkk., 2020), atau lebih dikenal sebagai sebuah metode pembelajaran dengan memberikan materi kepada siswa diawal pelajaran serta memberi contoh soal dan tanya jawab. Kegiatan pembelajaran seperti ini dapat menyebabkan siswa menjadi kurang aktif dalam kegiatan belajarnya. Saat siswa diberi kesempatan bertanya, hanya sedikit dari mereka yang berani melakukannya walaupun sebagian besar mereka masih meragukan pengetahuan konseptual yang mereka yakini.

Menurut hasil studi Liunome, Daniel \& Taneo (2020) bahwa terdapat peningkatan pencapaian belajar matematika siswa dengan pembelajaran kooperatif TPS. Hasil studi Laja \& Retnawati (2019) menyatakan bahwa berbagi informasi kepada teman-teman dalam konteks pembelajaran TPS membuat aktivitas siswa di kelas menjadi lebih baik. Pencapaian hasil belajar matematika siswa kelompok pembelajaran TPS lebih dari pembelajaran kooperatif lainnya (Kusuma \& Maskuroh, 2018; Kusuma, Safa'udin \& Rahayu, 2018; Rahmawati \& Hanipah, 2018). Kemudian, pembelajaran TSTS memberikan pencapaian matematis yang lebih baik dari pada pembelajaran kooperatif NHT dan konvensional (Rahmawati dkk., 2020). Menurut studi Murti, Yuni \& Zuhriyah (2019), pencapaian kemampuan siswa kelompok pembelajaran TSTS tidak lebih dari pembelajaran kooperatif tutor sebaya. Lebih lanjut, pembelajaran TSTS bisa digunakan dalam semua mata pelajaran dan semua tingkat usia siswa, kecenderungan belajar siswa menjadi lebih bermakna, lebih berorientasi pada keaktifan, membantu meningkatkan minat dan prestasi belajar. Menurut Kurniasi \& Vebrian (2019) bahwa dibutuhkan bantuan belajar bagi peserta didik dalam proses pembelajarannya.

Berdasarkan beberapa hasil studi yang telah dirujuk sehingga dengan pembelajaran TPS dan TSTS diharapkan mampu meningkatkan pencapaian kemampuan siswa yang lebih efektif. Pembelajaran 


\section{Range: Jurnal Pendidikan Matematika Vol. 2 No. 1 Tahun 2020 Harun Al Afgoni, dkk}

TSP dan TSTS adalah dua tipe dari pembelajaran kooperatif di mana setiap siswa bersama kelompoknya akan mendiskusikan materi pembelajaran yang diberikan oleh guru, sehingga siswa tidak hanya melamun dalam menerima pelajaran tetapi dituntut untuk berpikir dan mendiskusikan jawaban dengan pasangannya (Liunome dkk., 2020; Laja \& Retnawati, 2019). Di sini, fokus studi diarahkan pada pencapaian kemampuan berpikir geometri siswa tingkat rendah. Dalam teori van Hiele, tiga level awal berpikir geometri adalah visualisasi, analisis, dan abstraksi (van de Walle, Karp \& Bay-Williams, 2017). Levellevel berpikir tersebut dapat sejajar dengan kemampuan geometri siswa menurut studi Sudirman dkk. (2020). Oleh karena itu, studi ini bertujuan menganalisis pencapaian kemampuan berpikir geometri tingkat rendah siswa antara mereka yang dalam kelompok pembelajaran TPS dan TSTS.

\section{Metode Penelitian}

Penelitian kuantitatif ini adalah dengan desain postest only control group. Satu kelompok siswa belajar geometri dengan model TPS dan satu kelompok yang lain dengan model TSTS. Kelompok siswa dengan model TPS adalah sebanyak 30 orang dan kelompok yang dengan model TSTS juga sebanyak 30 orang. Sampel penelitian ini adalah siswa SMP di daerah Jakarta Timur.

Studi ini fokus pada kemampuan berpikir geometri siswa pada materi segitiga. Kemampuan berpikir geometri beserta dengan level-levelnya menjadi perhatian penting dalam pengembangan indikator dan membuat instrumen. Kami merujuk pada literatur van de Walle dkk. (2017) karena bukunya telah merinci tentang objects dan products of thought untuk setiap level berpikir geometri. Misalnya, objects dan products of thought pada level abstraksi berturut-turut adalah properti bidang datar dan hubungan antar properti itu. Instrumen yang dibuat kemudian diselesaikan siswa sehingga diperoleh data.

Data yang diperoleh kemudian dianalisis dengan statistik deskriptif dan inferensial. Statistik deskriptif yang disajikan adalah mean dan simpangan baku. Kemudian statistik inferensial yang digunakan untuk analisis data adalah dua uji prasyat analisis statistik (jika diperlukan) dan uji-t. Uji persyaratan analisis statistik adalah uji normalitas dengan uji Lilliefors dan uji homogenitas dengan uji- $F$. Setelah data berdistribusi normal dan variansinya homogen berdasarkan uji normalitas dan homogenitas, analisis kemudian dilanjutkan dengan analisis parametrik menggunakan uji-t.

\section{Hasil Penelitian dan Pembahasan}

\section{Data Kelompok Pembelajaran Kooperatif TPS}

Dari pencapaian siswa pada kelompok yang menggunakan model pembelajaran TPS, mereka memperoleh rentang nilai antara 86 sebagai nilai maksimal dan 59 sebagai nilai minimal. Dari data tersebut diperoleh rata-rata $=74,3$ dan simpangan baku=7,1.

Tabel 1. Distribusi Frekuensi Data Siswa Kelompok TPS

\begin{tabular}{cccc}
\hline Interval & Titik Tengah & Frekuensi & Batas Nyata \\
\hline $59-63$ & 61 & 1 & $58,5-63,5$ \\
\hline $64-68$ & 66 & 6 & $63,5-68,5$ \\
\hline $69-73$ & 71 & 8 & $68,5-73,5$ \\
\hline $74-78$ & 76 & 6 & $73,5-78,5$ \\
\hline $79-83$ & 81 & 5 & $78,5-83,5$ \\
\hline $84-88$ & 86 & 4 & $83,5-88,5$ \\
\hline
\end{tabular}

Berdasarkan Tabel di atas, diketahui bahwa nilai pencapaian kemampuan berpikir geometri tingkat rendah siswa dikelompokan dalam enam interval dengan panjang intervalnya adalah lima. Merujuk pada Tabel tersebut, berikut adalah histogram dan poligon frekuensinya. 


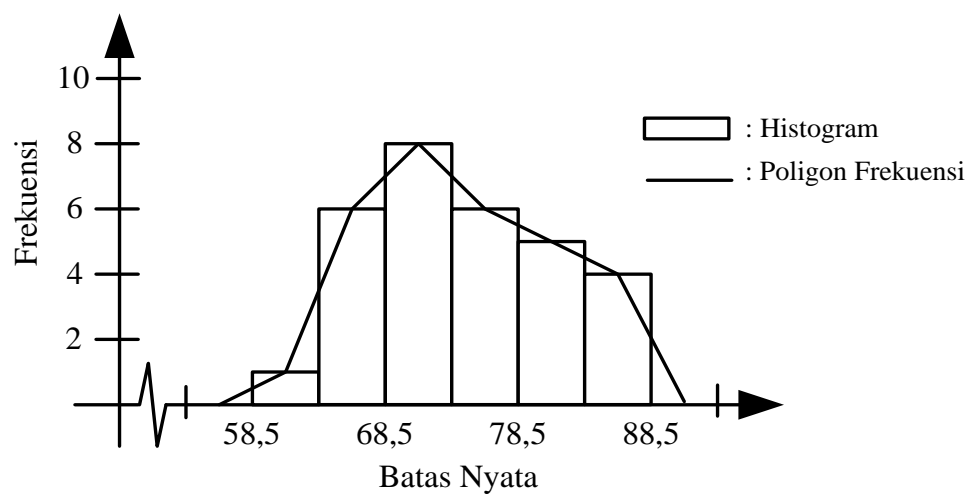

Gambar 1. Histogram dan Poligon Frekuensi

Pencapaian Kemampuan Siswa Kelompok TPS

2. Data Kelompok Pembelajaran Kooperatif TSTS

Dari pencapaian siswa pada kelompok yang menggunakan model pembelajaran TSTS, mereka memperoleh rentang nilai antara 82 sebagai nilai maksimal dan 55 sebagai nilai minimal. Dari data tersebut diperoleh rata-rata $=67,3$ dan simpangan baku=8,3.

Tabel 2. Distribusi Frekuensi Data Siswa Kelompok TSTS

\begin{tabular}{cccc}
\hline Interval & Titik Tengah & Frekuensi & Batas Nyata \\
\hline $55-59$ & 57 & 6 & $54,5-59,5$ \\
\hline $60-64$ & 62 & 8 & $59,5-64,5$ \\
\hline $65-69$ & 67 & 4 & $64,5-69,5$ \\
\hline $70-74$ & 72 & 5 & $69,5-74,5$ \\
\hline $75-79$ & 77 & 4 & $74,5-79,5$ \\
\hline $80-84$ & 82 & 3 & $79,5-84,5$ \\
\hline
\end{tabular}

Berdasarkan Tabel di atas, diketahui bahwa nilai pencapaian kemampuan berpikir geometri tingkat rendah siswa juga dikelompokan dalam enam interval dengan panjang intervalnya adalah lima. Merujuk pada Tabel tersebut, berikut adalah histogram dan poligon frekuensinya.

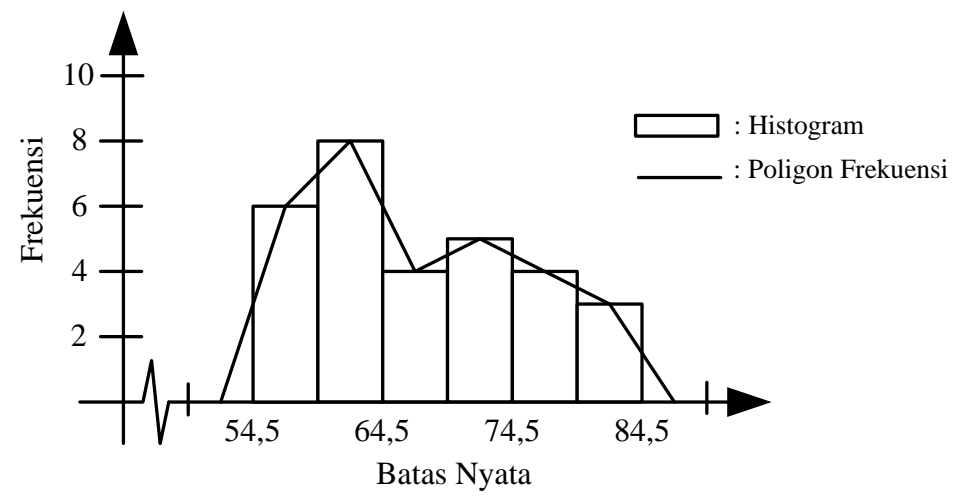

Gambar 2. Histogram dan Poligon Frekuensi Pencapaian Kemampuan Siswa Kelompok TSTS 


\section{Analisis Perbedaan Pencapaian Kemampuan Bepikir Geometri}

Hasil uji normalitas data kemampuan berpikir geometri tingkat rendah siswa digunakan untuk menyimpulkan apakah berdistribusi normal atau tidak. Untuk itu, maka digunakan uji lilliefors dengan taraf signifikansi sama dengan 0,05 . Berdasarkan hasil perhitungan diperoleh $L_{\text {hitung }}$ untuk data kelompok pembelajaran TPS sebesar 0,1368 dan diperoleh $L_{\text {hitung }}$ untuk data kelompok pembelajaran TSTS sebesar 0,122 . Kedua nilai tersebut dinyatakan bernilai kurang dari apabila dibandingkan dengan $L_{\text {tabel }}$ sebesar 0,161 pada $\alpha=0,05$. Dengan demikian, dari data kedua kelompok pembelajaran tersebut berdistribusi normal dan dinilai memenuhi persyaratan untuk dianalisis variansinya.

Uji homogenitas varians antar kelompok pembelajaran dilakukan dengan uji- $F$ dengan ketentuan $F_{\text {hitung }}$ kurang dari $F_{\text {tabel. }}$. Hasil uji homogenitas diperoleh $F_{\text {hitung }}=1,37$ dan $F_{\text {tabel }}=1,85$ pada taraf signifikansi 0,05 . Karena $F_{\text {hitung }}=1,37<1,85=F_{\text {tabel }}$ ) maka disimpulkan bahwa sampel kedua kelompok pembelajaran itu mempunyai varians yang homogen.

Hasil uji distribusi dan variansi data telah meyimpulkan analisis untuk uji- $t$ menggunakan statistik parametrik. Hipotesis penelitian yang telah dirumuskan adalah terdapat perbedaan pencapaian kemampuan berpikir geometri tingkat rendah siswa antara pembelajaran TPS dan TSTS. Berdasarkan hasil analisis data, diperoleh $t_{\text {hitung }}=3,488$, sedangkan perhitungan $t_{\text {tabel }}$ adalah 2,002, sehingga $t_{\text {hitung }}=3,488>2,002=t_{\text {tabel. }}$. Kesimpulan analisis uji hipotesisnya adalah terdapat perbedaan pencapaian kemampuan berpikir geometri tingkat rendah siswa antara pembelajaran TPS dan TSTS.

\section{Diskusi Hasil Penelitian}

Merujuk pada pencapaian siswa kelompok pembelajaran TPS, rata-rata mereka lebih dari kelompok pembelajaran TSTS. Hasil studi ini sama dengan beberapa studi (misalnya Kusuma \& Maskuroh, 2018; Kusuma dkk., 2018; Rahmawati \& Hanipah, 2018) bahwa pencapaian hasil belajar matematika siswa kelompok pembelajaran TPS lebih dari pembelajaran kooperatif tipe lainnya. Kemudian tidak bertentangan pula dengan studi Murti dkk. (2019) bahwa pencapaian kemampuan siswa kelompok pembelajaran TSTS tidak lebih dari pembelajaran kooperatif lain.

Berdasarkan kedua Gambar histogram dan poligon frekuensi, dengan tolak ukur pada interval nilai pencapaian, sehingga kami memprediksi bahwa pencapaian kemampuan berpikir geometri siswa sebagian besar berada pada level analisis. Dengan kata lain, kemampuan berpikir geometri sebagian besar siswa baru memulai untuk mampu menemukan hubungan antar properti pada bidang datar sebagai product of thought mereka. Ketika membandingkan dengan hasil studi Sudirman dkk. (2020), maka ada sedikit perbedaan karena siswa dalam studi ini cenderung belum secara keseluruhan mampu menerapkan konsep geometri sementara konsep geometri yang akan diaplikasikan adalah hasil mengabstraksi, atau merupakan konsep yang akan diaplikasikan setelah menemukan hubungan antar properti pada bidang geometri tertentu. Hal tersebut juga tidak bertentangan dengan pernyataan Rahayu \& Alghadari (2019) bahwa sebagian besar siswa hanya menghafal rumus algoritmik tanpa memahami konsepnya secara mendalam.

\section{Kesimpulan}

Dari hasil penelitian, diketahui kesimpulan berdasarkan analisis data kuantitatif bahwa terdapat perbedaan pencapaian kemampuan berpikir geometri tingkat rendah siswa antara pembelajaran TPS dan TSTS. Lebih lanjut, rataan pencapaian siswa kelompok TPS lebih dari kelompok TSTS.

Berdasarkan kesimpulan penelitian, saran yang dapat diberikan adalah: (1) dengan adanya perbedaan pencapaian kemampuan berpikir geometri tingkat rendah siswa antara pembelajaran TPS dan TSTS, di mana rata-rata data siswa kelompok pembelajaran TPS lebih dari TSTS, maka belajar konsep segitiga pada siswa SMP lebih baik dengan pembelajaran kooperatif tipe TPS; (2) perlu diadakan penelitian lebih lanjut khusus pada level berpikir geometri siswa karena berdasarkan Gambar histogram dan poligon frekuensi dalam studi ini terlihat bahwa pencapaian siswa cenderung pada level analisis. 


\section{Range: Jurnal Pendidikan Matematika Vol. 2 No. 1 Tahun 2020 Harun Al Afgoni, dkk}

\section{Daftar Pustaka}

Alghadari, F., \& Herman, T. (2018). The obstacles of geometric problem-solving on solid with vector and triangle approach. Journal of Physics: Conference Series, 1132(1), 012046.

Alghadari, F., Herman, T., \& Prabawanto, S. (2020). Factors Affecting Senior High School Students to Solve Three-Dimensional Geometry Problems. International Electronic Journal of Mathematics Education, 15(3), em0590.

Kurniasi, E. R., \& Vebrian, R. (2019). Pengembangan Pembelajaran Drill and Practice Berbantuan Video Mata Kuliah Kalkulus Integral. AKSIOMA: Jurnal Program Studi Pendidikan Matematika, 8(3), 448-456.

Kusuma, A. P., Safa'udin, M., \& Rahayu, R. (2018). Eksperimentasi Model Pembelajaran TPS dan TAI terhadap Hasil Belajar Matematika pada Materi Lingkaran. Jurnal Tecnoscienza, 3(1), 29-40.

Kusuma, A. P., \& Maskuroh, M. (2018). The Differences of Mathematics Learning Outcomes between Think Pair Share (TPS) and Number Heads Together (NHT). Al-Jabar: Jurnal Pendidikan Matematika, 9(1), 19-24.

Laja, Y. P. W., \& Retnawati, H. (2019). Apakah Think-Pair-Share Dapat Mengurangi Kecemasan Matematika Siswa SMP?. RANGE: Jurnal Pendidikan Matematika, 1(1), 57-62.

Liunome, A. V., Daniel, F., \& Taneo, P. N. (2020). Motivasi Dan Prestasi Belajar Matematika Siswa Pada Pembelajaran Model Kooperatif Tipe TPS. RANGE: Jurnal Pendidikan Matematika, 1(2), 145-151.

Minarti, E. D., Wahyudin \& Alghadari, F. (2018). Student's conceptions and geometry problem-solving of the distance in cube. Journal of Physics: Conference Series, 1132(1), 012033.

Murti, Y., Yuni, Y., \& Zuhriyah, A. (2019). Perbedaan Hasil Belajar Matematika Siswa pada Materi Statistika antara Metode Tutor Sebaya dan Two Stay Two Stray. Prosiding Seminar Nasional Pendidikan STKIP Kusuma Negara, 2019, (pp. 1-6). Jakarta: STKIP Kusuma Negara.

Rahayu, T., \& Alghadari, F. (2019). Identitas Bayangan Konsep Limas: Analisis Terhadap Konsepsi Matematis Siswa. Inomatika, 1(1), 21-30.

Rahmawati, N. K., \& Hanipah, I. R. (2018). Penerapan Model Pembelajaran Kooperatif Tipe Think Pair Share (TPS) Dan Model Pembelajaran Kooperatif Tipe Student Team Achievement Division (STAD) Terhadap Hasil Belajar Matematika Siswa Pada Materi Garis Singgung Lingkaran. NUMERICAL: Jurnal Matematika dan Pendidikan Matematika, 43-48.

Rahmawati, N. K., Kusuma, A. P., \& Suparman, P. (2020). Penerapan Model TSTS dan NHT Pada Materi Persamaan Fungsi Eksponen. Jurnal Pendidikan Matematika dan IPA, 11(1), 154-162.

Rosilawati, R., \& Alghadari, F. (2018). Konsepsi Siswa pada Suatu Bentuk Bangun Ruang Terkait dengan Rusuk dan Diagonal Sisi. Prisma, 7(2), 164-176.

Sudirman, S., Son, A. L., Rosyadi, R., \& Fitriani, R. N. (2020). Uncovering the Students' Mathematical Concept Understanding Ability: a Based Study of Both Students' Cognitive Styles Dependent and Independent Field in Overcoming the Problem of 3D Geometry. Formatif: Jurnal Ilmiah Pendidikan MIPA, 10(1), 1-12.

Tarwana, W., Alghadari, F., \& Marlina, A. (2019). Meningkatkan Pemahaman Konsep Geometri Siswa melalui Pembelajaran Kooperatif Jigsaw. Prosiding Seminar Nasional Pendidikan STKIP Kusuma Negara, 2019, (pp. 1-7). Jakarta: STKIP Kusuma Negara.

Theresia, D., Syafi'i, M., \& Vioreza, N. (2020). Pencapaian Kemampuan Low Order Thinking Siswa antara Pembelajaran Probing Prompting dan Matematika Realistik. Journal of Instructional Mathematics, 1(1), 31-37.

Van de Walle, J. ., Karp, K. ., \& Bay-Williams, J. . (2017). Elementary and Middle School Mathematics: Teaching Developmentally. USA: Pearson Education. 